\title{
APPRAISAL OF THE DAIRY CAPITAL VALUE ON THE TERRITORY OF THE PESTER PLATEAU
}

\author{
Mersida Jandrić ${ }^{1}$, Vladimir Zakić ${ }^{2}$ \\ *Corresponding authorE-mail: mersida.jandric@hotmail.com
}

\begin{tabular}{l} 
A R T I C L E I N F O \\
Original Article \\
Received: 13 April 2018 \\
Accepted: 11 June 2018 \\
doi:10.5937/ekoPolj1802673J \\
UDC 330.143+637.1(497.11 Pešter) \\
\hline
\end{tabular}

Keywords:

milk, dairy, Pester, evaluation of value, discount method.

JEL: G32, Q12

\section{A B S T R A C T}

The goal of the paper is to do research of adequacy of the discounting method apply of future results for the evaluation of capital value in dairy industry, on an individual case.

Appraisal of the capital value is a complex procedure of researching, studying, analysing and evaluating numerous factors, which have an effect on an enterprise's value. The appraisal of the dairy capital value from the Pester plateau was presented in the paper. Need for assessment was the change of the dairy's ownership structure. The selected value context in evaluating the enterprise value was "a fair value", while there was applied an output approach i.e. the future results discounting method, because it was about an enterprise that continued to operate. Discounting the future expected outputs represents a current value of future expected outputs with a discount rate, which reflects uncertainty resulted by the expected yields.

According to this paper's results, there has been established that the discounting methods of DCF future results can successfully apply in the dairy capital evaluation that continued to operate

(C) 2018 EA. All rights reserved.

\section{Introduction}

The value of an enterprise is determined by property it disposes with, size and quality of realised investments, the achieved level of development, and the achieved business results, positioning on the market, personnel and management. Future developmental plans, the predictable business activity and their results also have an effect on the capital value. That is why the market value of individual parts of the property cannot be the only measure in order to form an enterprise value. Combining more methods that provide different results enables that the proposed value of capital reflects at the same time values obtained from different points of view. Crossing the results obtained by different methods relativizes the inevitable subjectivity of an appraiser to a certain extent.

1 Mersida Jandrić, Doctoral student, University of Belgrade, Faculty of Agriculture, Nemanjina 6, 11080 Belgrade Zemun, E-mail: mersida.jandric@hotmail.com

2 Vladimir Zakić, Associate Professor, University of Belgrade, Faculty of Agriculture, Nemanjina 6, 11080 Belgrade Zemun, E-mail: zakic@agrif.bg.ac.rs ORCID ID 0000-0002-1385-916X 
Selection of a method that is going to be applied in the capital value appraisal of each particular enterprise depends first of all on the purpose of appraisal. The capital appraisal of a specific enterprise can be done for various purposes, such as: buying/ selling of a company, merging of enterprises, entering of an enterprise to the stock market, liquidation of an enterprise, etc.

Enterprises can have different characteristics in terms of business, and an owner's goals vary from one to the other enterprise. It means that not only one method or formula for the evaluation of any enterprise can be used, in any situation and purpose. Therefore the economic science has developed three approaches of evaluation, which can be used in practice: the yield, market and cost approach (Rodić et al., 2010). The selection of an adequate method depends on several factors: the possibility to project further business, size of an enterprise, financial position of an enterprise, etc. The selected methods are more convenient for the appraisal of a specific enterprise - the final result will be closer to the market value of an enterprise.

\section{Materials and methods}

The goal of this paper is to research adequacy of the future results discounting, method application for the appraisal of a capital value in dairy industry.

The yield method has found its wide application in evaluating an agricultural enterprise, perennial plantations, milking herd, agricultural equipment, agricultural buildings, agricultural land, etc. (Vukelić 1998, Gogić 1990, Tica 1993, Ivanović et al., 2006, Ivanović 2006, Tica 1993).

The appraisal of a dairy from the Pester Plateau is based on a detailed analysis of financial and management statements, future development plan, anticipated business activities and results that are expected. The appraisal procedure is consisted of two parts: a sum of current values of future cash flows and a residual value ${ }^{3}$. The selected context of values is the "fair value“.

The basic characteristics, on which the appraisal of capital value is based, are: a value of an enterprise is equal to a current value of future interests that an owner will have; a value cannot be expressed always in only one number and a value is appraised is a specific moment of time - the date of assessment (Leko et al., 1997).

Within the yield approach, there are two methods in the assessment of capital value, and these are: capitalization of the achieved results and discounting of the future results. The yield approach is applied if yields can be projected relatively reliable and if there can be expected their significant differentiation from the existing ones, due to changes in doing business or the expected changes in the environment of an enterprise. Determination of a residual value is done according to a projected cash flow or profit.

3 Residual value is calculated in a way that a current value of the last residual year multiplies with $(1+$ growth rate in the residual period) and then it divides by the Gordon's factor that is obtained by deducting a growth rate from a discount rate in the residual period. 
Finally, the projected yields and residual value are discounted i.e. reduced to a current value in order to set an enterprise's value. The future yields are projected up to the moment in which they reach a stable level.

The method of discounted cash flow (DCF) is the basic method for the assessment of an enterprise's capital value. Together with the capitalization method, it belongs to the yield approach in the appraisal of capital value. Both methods are based on the future projected results of business (net profit or net cash flow).

The essence of this DCF method is to observe an enterprise as a unique mechanism i.e. the system for making a profit (gain), and this ability directly defines this system value. A value of the enterprise (and capital) is directly dependable on the ability of a specific enterprise to fructificate an engaged capital and make a profit.

Difference between the DCF method and the capitalization method comes from important features of the future projected period. The capitalization method is enforceable if an appraised enterprise has reached a stable level of profit and inflow, so some significant changes will not be expected in the future. If some significant changes in a projected period is expected (usually a higher level of profit and net inflow), the DCF method presents more realistic the yield approach in appraisal of the capital value (Leko et al., 1997).

Hence, the method of discounted cash flow (DCF) presumes continuation of the enterprise's business also after the projected period, by the stable rates, which means that a significant part of the enterprise's value is in this remaining i.e. residual period. A value of the enterprise in residual is set in different ways, and the most famous is the Gordon's model.

The DCF method is based on a fact that ,the value of an enterprise's capital is equal to a sum of current values of future net inflows that can be realised by owners in an unlimited long period“" (Leko et al., 1997).

In order to apply this assessment method, it is necessary to choose the cash flow definition, project a cash flow in a selected future period, calculate a discount rate, calculate a sum of NCF current values in a projected period, calculate a residual value, set a final value of the enterprise's capital and adjust to a value of non-operating assets and/or the unused business funds.

The capital value, appraised by applying the DCF method, is consisted of two components: sum of the current values of the projected annual NCF and the residual value. A period of the enterprise's economic life, which hasnt been comprised by the projection, is called the residual, and therefore a component of capital value is called the residual value.

There are several ways to calculate the residual value (discounted liquidation value, a method of capital/value multiplier, etc.). The Gordon's model uses to calculate the residual value, by the Regulation on the Method of Determining the Value of Capital:

$$
\mathrm{RV}=\mathrm{DNCFr} /(\mathrm{DR}-\mathrm{GRr})
$$

RV - Residual Value, DNCFr - Discounted Net Cash Flow in Residual Year, DR Discount Rate, GRr - Growth Rate in Residual. 
The NCF of a residual year calculates in a way the NCF from the last year of a project (when stabilization of business achieves) increases for a growth rate in residual. After that, the current value of NCFr calculates by using a discount factor.

The growth rate in residual means the continuous increase in NCF, from year to year in a residual period, which hasn't been encircled by the projection. Theoretically, the growth rate cannot be the same as the discount rate, since the result would be infinite. By the Regulation on the method of determining capital was determined that an upper limit of the growth rate was $4 \%$.

\section{Results and discussion}

Adairy building was made according to the legal provisions valid for these purposes. Location of the existing building is suitable, because there is no similar building in surrounding; a favourable raw material base; power supply is bigger than real and maximum needs of the dairy; a green belt around the building is sufficient for inevitable traffic arteries and parking spaces, as well as the ecological arrangement of a park within the dairy. Terrain on which the dairy is located is characterized by the favourable wind rose.

The dairy doesn't emit a significant quantity of heat, noise, radiation and there is also no unpleasant smells on condition of maintaining the sanitary hygiene and respecting the projected technological process. Monitoring air quality, soil, noise, electromagnetic radiation and heat emission are not necessary to be done, as it is defined by the Study on the impact of the project on environment. Wastewater, with the only possible significant impact on the environment, gathers in three waterproof septic tanks.

The main forces of the enterprise are availability and vicinity of the raw material base from the ecologically clean area, which significantly reduces the costs of transport (Jandrć et al., 2016). The environment provides a great opportunity that the enterprise expands its range of products, and passes from the conventional production to the production of organic products in the near future (Jandrć et al., 2014). A brand has become recognizable in a short time on the local market. The reason for this quick brand recognition is partly the awareness of consumers and greater focus on brands from the ecologically clean areas. On the other hand, the biggest threat the enterprise is exposed to is the enlargement of a dairy sector and numerous competitors. In the coming period of 10-15 years, the manufacturers consider that their firms will increase the volume of production and $75 \%$ of the total manufacturers will stay in production, while the rest $25 \%$ will leave production (Zarić et al., 2012).

Together with the competitive threat is also present the lack of adequate and educated workforce, as the main defectiveness of the enterprise for the moment. There is especially expressed the financial illiteracy of owners and managers of the enterprise. The fact is that a large number of people worldwide have lost their belongings as a result of insufficient financial literacy. The financial literacy enables the optimal use of the source of finance and decrease in the assets liquidity risk (Zakić et al., 2017). 
The appraised value of a building owned by the dairy is $165987 €$ or $250 € / \mathrm{m}^{2}$ of useful surface. Surface area of the building in the ground floor is $670 \mathrm{~m}^{2}\left(610.35 \mathrm{~m}^{2}\right.$ of useful surface). The building is located so that it provides unobstructed circulation of traffic. It consists of entireties predicted for milk processing. The building has a road infrastructure, as well as land in its possession. After several disputes with a municipality, land was bought, by a court verdict, at the evaluated market value of 20 $€ / \mathrm{m}^{2}$. The costs of the dispute are not included in the evaluation of land value.

While investing and building, an owner has mostly used own workforce (family members), and therefore the labour and maintenance costs haven't been registered. For that reason, in the appraisal of the building several appraisal methods had to be combined, in order to get more reliable information. In the value appraisal of builtin material and a cost price of the following documentation, there was used the cost approach, and regarding the price of.construction work, the market approach was used. Finally, there was calculated a price per $\mathrm{m}^{2}$ of useful surface.

Table 1 - Appraised value of investments

\begin{tabular}{|l|l|r|r|}
\hline No. & Investment structure & Amount $€$ & $\%$ share \\
\hline 1 & Building & 165,987 & 49.22 \\
\hline 2 & Equipment & 138,000 & 40.92 \\
\hline 3 & Permanent working capital & 33,268 & 9.86 \\
\hline 4 & Total & $\mathbf{3 3 7 , 2 5 5}$ & 100.00 \\
\hline
\end{tabular}

Source: Calculation of authors

During the procedure of the building value appraisal, every element of the building was evaluated by an expert, and documentation and total area of the rooms were checked. A value of the building construction was determined in accordance to a construction price in the moment of appraisal, and it was further multiplied with a total useful area of the building. Costs of the investment-technical documentation, construction costs, and costs of the building site arrangement and a purchase value of installations were included in price. A pre-calculated value of the building amounted $167208 €$, which was approximate to the appraised value of the building. Regarding that the building was in use only several months in the previous year (probation period), amortization for this period was ignored.

The evaluated value of equipment on the appraisal date was $138000 €$. During the procedure of the equipment value appraisal was done the inventory of equipment, which was reflecting real condition of equipment on the day of the appraisal. A qualified appraiser for this kind of equipment was made an insight into the real condition of equipment and was evaluated its functional, technical and economic backwardness by lines and groups.

In the previous year, the dairy was procured through leasing most of the used equipment for processing milk and dairy products by a net amount of $56689,60 €$. The conditions for leasing were: repayment for 5 years, an effective rate of $9.76 \%$, a nominal rate of interest of $6.99 \%+$ six-months EURIBOR, and the calculated currency was EUR 
(118.23 RSD/1 EUR). A plan of lease repayment was set through the fixed monthly instalments in the amount of 890.80 EUR.

At the moment of the enterprise's capital value appraisal, the remaining leasing liabilities were $40976.80 €(2016$ - 10 689.60; 2017 - 10 689.60; 2018 - 10 689.60; 2019 - 8 908), while the liabilities for interest were $4911.50 €(2016-2189.16,2017$ - 1 575.68, 2018 - 918.09; 2019 - 228.57).

Table 2 - Structure of financing

\begin{tabular}{|l|l|r|r|}
\hline No. & Structure & Amount $€$ & \% share \\
\hline 1 & Equity capital & $296.278,20$ & 87.85 \\
\hline 2 & Borrowed funds & $40.976,80$ & 12.15 \\
\hline 3 & Total & $\mathbf{3 3 7 . 2 5 5 , 0 0}$ & 100.00 \\
\hline
\end{tabular}

Source: Calculation of authors

From the moment machines were put into operation, an investor has changed most of the current equipment with the new one, and therefore the new part of the equipment has got a completely new value. Investments that were invested in additional parts of the equipment were mainly entered to the debit of costs, and some weren't even booked. This is the reason why an expert has to be involved in the appraisal of the equipment value. The expert appraised the equipment by the combination of the market and cost approach. For the part of the equipment that was obtained as non-amortized, the cost approach in the value appraisal was applied, while the market approach was used regarding the part of the equipment that was partly amortized.

Necessary working assets, as well as the spontaneous sources, were planned based on the previous experience and expected changes at the level of these assets or sources engagement. The appraised value of working assets was based on a turnover coefficient (Andrić et al., 2005) and was amounted $33268 €$. Before starting to operate, the dairy did segmentation of the purchasing and sale market, and in the previous period, the dairy didn't have a problem with receivables. In production of 3000 litres of milk per day, the working assets were $30000 €$.

The appraised value of the total investment was $337255 €$. Most of it was invested in the building and equipment. The capital market wasn't adjusted to financing of small enterprises by the financial institutions, while the business banks weren't in of tune with their crediting (Jandrić et al., 2015). For that reason, the dairy that was evaluated was mostly depending on the internal financial resources $(87.85 \%)$, while a part of the equipment $(12.15 \%)$ was financed by the borrowed funds.

During the production was projected, there was started from the existing data of the dairy. In accordance to the production of 3370 litres of milk products and their selling prices, an average selling price for 1 litre of milk products was calculated $(0.58 €)$. 
According to the enterprise's developmental plan, the production value for the following 5 years was projected. The plan of development was real, because it was about the building of processing capacity 20000 litres per day. At the moment of the appraisal, the dairy was working with only $16.85 \%$ of processing capacity. The reason for a low degree of utilization of the processing capacity was a very young enterprise, which still was training workers.

Table 3 - Income projection $(€)$

\begin{tabular}{|l|c|c|c|c|c|}
\hline Year of projection & I & II & III & IV & V \\
\hline Dairy products 1/day & 3,370 & 4,380 & 5,694 & 7,404 & 9,625 \\
\hline Year & $\mathbf{7 1 3 , 4 2 9}$ & $\mathbf{9 2 7 , 2 4 6}$ & $\mathbf{1 , 2 0 5 , 4 2 0}$ & $\mathbf{1 , 5 6 7 , 3 1 0}$ & $\mathbf{2 , 0 3 7 , 7 9 5}$ \\
\hline
\end{tabular}

Source: Calculation of authors

Calculation of the direct material costs is related to the costs of raw material and packaging. In order to anticipate these expenses, it is necessary to be familiar with normative by a product, a permitted percentage of loss and a purchasing price of raw material and packaging.

Table 4 - Net cash flow (NCF)

\begin{tabular}{|r|l|r|r|r|r|r|}
\hline \multirow{2}{*}{\multicolumn{2}{|l|}{}} & \multicolumn{5}{c|}{ Year } \\
\cline { 3 - 7 } & I & \multicolumn{1}{c|}{ II } & \multicolumn{1}{c|}{ III } & \multicolumn{1}{c|}{ IV } & V \\
\hline 1. & Net profit & 112,792 & 161,696 & 230,386 & 324,115 & 445,982 \\
\hline 2. & Amortization & 24,620 & 24,620 & 24,620 & 24,620 & 24,620 \\
\hline 3. & Interests on credit & 2,189 & 1,576 & 918 & 229 & \\
\hline 4. & Value remainder of investment & & & & & 264,156 \\
\hline $\mathbf{5 .}$ & NCF without the project value remainder & $\mathbf{1 3 9 , 6 0 1}$ & $\mathbf{1 8 7 , 8 9 2}$ & $\mathbf{2 5 5 , 9 2 4}$ & $\mathbf{3 4 8 , 9 6 4}$ & $\mathbf{4 7 0 , 6 0 2}$ \\
\hline $\mathbf{6 .}$ & NCF with the project value remainder & $\mathbf{1 3 9 , 6 0 1}$ & $\mathbf{1 8 7 , 8 9 2}$ & $\mathbf{2 5 5 , 9 2 4}$ & $\mathbf{3 4 8 , 9 6 4}$ & $\mathbf{7 3 4 , 7 5 8}$ \\
\hline
\end{tabular}

Source: Calculation of authors

Raw milk is paid by a percentage of milk fat. Samples show that milk fat in the raw milk range from $3.6 \%-4.2 \%$. While calculating the raw milk price, there was taken into consideration an upper value of milk fat in order to decrease the risk of unforeseen costs or the increase in redemption prices of milk. A price of 1 litre of raw milk by this calculation was $0.23 €$. An average price of packaging was $0.083 €$, and it was calculated according to the structure and quantity of products and their packaging purchase price.

The workforce specification by the qualification structure was done based on appraisal of type, complexity and scope of work that will be done in the dairy. The qualification structure and a number of performers were set according to adopted technological procedures of production and the selected technological equipment i.e. the level of mechanization of production lines and the adopted organization of work.

While calculating the labour and contribution cost, the baseline data was a number of currently employed workers and the amount of their personal incomes and contributions. In the second year of the projection, the increase in personal incomes for $30 \%$ and employing 
two more workers in production was planned. In the following years of the projection was planning to employ two workers per production and the increase in personal incomes for $20 \%$ for every year individually. The contributions were projected in the amount of $60 \%$.

A final projection of a balance sheet for the next five years was achieved by comprising all aggregate amounts of all previously projected positions. The cash flows projection by years was done until the moment of the cash flows stabilization. Selected definition of NCF was "before the debt service repayment". Incomes and outcomes i.e. the business result was calculated in the projected period with satisfactory certainty.

Table 5 - Discounted Cash Flows

\begin{tabular}{|c|c|c|c|}
\hline & Nominal value & Discount factor (7\%) & DCF \\
\hline 0 & & 1.0000 & \\
\hline 1 & 139,601 & 0.9346 & 130,472 \\
\hline 2 & 187,892 & 0.8734 & 164,105 \\
\hline 3 & 255,924 & 0.8163 & 208,911 \\
\hline 4 & 348,964 & 0.7629 & 266,225 \\
\hline 5 & 470,602 & 0.7130 & 335,539 \\
\hline $6^{*}$ & 264,156 & 0.7130 & 188,343 \\
\hline$\sum$ of current values & & & $1,105,252$ \\
\hline
\end{tabular}

In accordance with the regulated methodology, the basic DCF value of the enterprise's capital was determined as a sum of the discounted value of net cash flows in the projected period and the discounted residual value. The discount factors were selected at the end of year, and were established based on a calculated discount rate of $7 \%$. The cash flows were reduced to the current value by using the appropriate discount factors (Gogić, 2014).

The yield value is a parameter that shows the volume of investment. The residual period is the period after the projection, and the residual value is the value of cash flow after the in detailed projection (Rodić et al., 2010).

The residual value was calculated by using the Gordon's model (cash flow in the last year was increased for an amount of the projected growth rate in residual).

The net cash flow in the last year was 470 602, and increased for the growth rate 472 955. The discount cash flow in the amount of 337216 was obtained by discounting the net cash flow of residual.

Since the projected growth rate in residual was $0.5 \%$, the calculated residual value was, by using the Gordon's model:

$\mathrm{RV}=337216 / 0.07-0.005=5187938$

while constructing the NCF a selected definition before the debt service repayment, the enterprise's capital value determines indirectly. The value of the dairy's long-term capital is a sum of the current values (1 $105252 €)$ and the residual value (5 $187938 €)$ i.e. $6193190 €$. 
The equity capital value is equal to the difference between an appraised long-term capital and a found amount of long-term liabilities on the day of the assessment. Thus, the value of the equity long-term capital was 6252213 (6 293190 - 40 977).

\section{Conclusion}

The DCF method was applied during the value appraisal of the total long-term capital of the dairy from the Pester Plateau. There started from the fact that the DCF method was presenting the yield approach more realistic, if significant changes in the projected period were expected. A higher profit and net inflow were expected regarding the dairy value that was appraised.

The selected context of value is ,the fair value context". The discount factors were chosen at the end of year, and were established based on the calculated discount rate of $7 \%$. The expected growth rate in residual was $0 / 5 \%$.

A real cash flow ',before the debt service repayment" and the evaluated value of cash flow in the residual period was projected by the applied method. Sums of the current values after 5 years were $1105252 €$ and the residual value $5187938 €$. The appraised value of the dairy's equity capital, by using the DCF method, was amounted $6252213 €$ on the day of the appraisal.

According to work results, there was determined that the DCF method can be successfully applied in appraisal of the dairy capital.

\section{Conflict of interests}

The authors declare no conflict of interest.

\section{References}

1. Andrić, J., Vasiljević Z., Sredojević, Z. (2005). Investments, Fundamentals of Planning and Analysis, University of Belgrade, Faculty of Agriculture, Belgrade [in Serbian: Investicije, Osnove planiranja $i$ analize, Univerzitet $\mathrm{u}$ Beogradu, Poljoprivredni fakultet, Beograd]

2. Vukelić, G. (1998). Valuation of Agricultural Enterprise Value, Endowment Andrijević, Belgrade [in Serbian: Procena vrednosti poljoprivrednog preduzeća, Zadužbina Andrijević, Beograd]

3. Gogić, P. (1990). Determination of the effectiveness of raising long-term farms using dynamic methods for evaluating the investment, Economics of Agriculture, No.6, 207-218, Beograd [in Serbian: Utvrdivanje efektivnosti podizanja dugogodišnjih zasada primjenom dinamičkih metoda za ocjenu investicije, Ekonomika poljoprivrede, Beograd]

4. Gogić, P. (2014). Cost theory with calculations in the production and processing of agricultural products, University of Belgrade, Faculty of Agriculture, Belgrade, [in Serbian: Teorija troškova sa kalkulacijama u proizvodnji i preradi poljoprivrednih proizvoda, Univerzitet u Beogradu, Poljoprivredni fakultet, Beograd] 
5. Ivanović, S. (2006). Determination of the yield value of the cow's milk, Economic of Agriculture, 53(4), 1039 - 1053, Beograd, [in Serbian: Utvrđivanje prinosne vrednosti staje za muzne krave. Ekonomika poljoprivrede]

6. Ivanović, S., Pajić, M., Miodragović, R. (2006). Analysis of silage combine yield value on family farms, Economic of Agriculture, Belgrade, 53(4), 1039 1053 [in Serbian: Analiza prinosne vrednosti silažnog kombajna na porodičnim gazdinstvima. Ekonomika poljoprivrede, Beograd]

7. Jandrić, M., Živković, D., Jelić S., Rajić, Z. (2014). Economic profitability of milk production and possibility of organic system development on Pešter for rural development cause, 10.7251/AGSY14041051J, Fifth International Scientific Agricultural Symposium „Agrosym 2014“

8. Jandrić, M.,Vasiljević, Z., Kovačević, V. (2015). Financing the dairy sector in rural areas of the Republic of Serbia: Pester region example, Journals „Agriculture \& Forestry”, Vol.61 Issue 1:273- 278, DOI:1017707/Agricult Forest. 61.1.34, Biotehnical Faculty of the University of Montenegro

9. Jandrić, M., Rajić, Z., Živković, D. (2016). Economic business analysis of daires from Pešter area, Book of proceedings (2651-2658), Agrosym, Bosnia and Herzegovina

10. Leko, V., Vlahović, A., Poznanić, V. (1997)., Capital appreciation, Economic Institute, Belgrade [in Serbian: Procena vrednosti kapitala, Ekonomski institut, Beograd]

11. Rodić, J., Filipović M. (2010). Company Value Evaluation, Asimex doo, Belgrade [in Serbian: Procena vrednosti preduzeća, Asimex doo, Beograd]

12. Tica, N. (1993). Evaluation of the Value of Agricultural Land, Bookkeeping and Practice, No.6, Belgrade [in Serbian: Procena vrednosti poljoprivrednog zemljišta, Knjigovodstvo i praksa, br.6, Beograd]

13. Tica, N. (1993)., Determining the yield value of the milking herd, Economic of agriculture, 40 (1-2), 47-53, Belgrade, [in Serbian: Utvrđivanje prinosne vrednosti muznog stada, Ekonomika poljoprivrede, 40 (1-2), 47-53, Beograd]

14. Zakić, V., Kovačević, V., Damnjanović, J. (2017). Significance of financial literacy for the agricultural holdings in Serbia, Economics of Agriculture, vol. 64, no. 4, Institute of Agricultural Economics, pp. 1687-1702, ISSN 03523462, UDC: 657.2.016:631.11(497.11)

15. Zarić, V., Vasiljević, Z., Petković., D, Raketić., B. (2012). Attitudes and expectations of the producers with Pešteri on the production and marketing of milk and dairy products, 47 th Croacian and 7 th Internacional Symposium on Agriculture, Book of proceedings (235-238), Opatija, Croatia [in Serbian: Stavovi i očekivanja proizvođača s Pešteri o proizvodnji i plasmanu mlijeka i mliječnih proizvoda, 47 th Croacian and 7 th Internacional Symposium on Agriculture, Book of proceedings (235-238), Opatija, Croatia] 